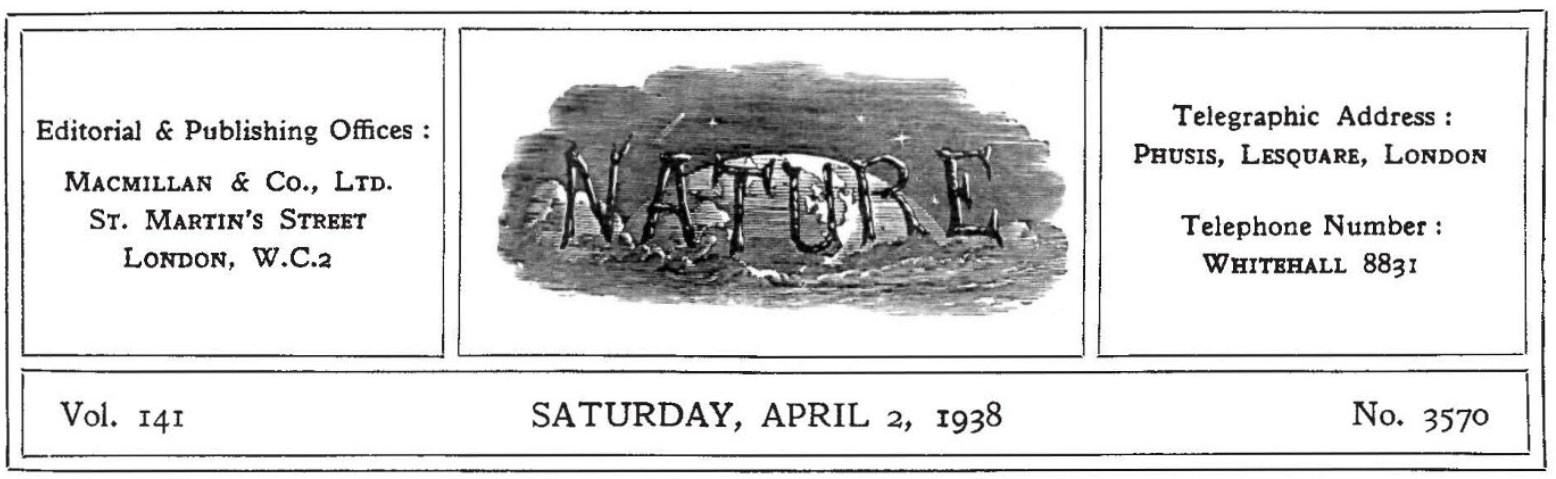

\title{
Civil Aviation in Great Britain
}

$\mathrm{T}^{\mathrm{H}}$ HROUGHOUT the post-War period, the development of civil aviation in Great Britain as in other countries has been warped by military demands. The report on the Economics of Air Transport in Europe submitted by M. Henri Bouché to the Air Transport Co-operation Committee of the League of Nations in 1935 revealed not only the uneconomic position of civil aviation in Europe generally, but also the way in which national prejudices or military arguments have deprived civil aviation of the freedom which would enable it to reap the advantages inherent in its potentially greater speed as compared with surface transport. In observations on the recently issued report of the Committee of Inquiry into Civil Aviation, which was under the chairmanship of Lord Cadman, the Government has admitted that the unprecedented effort of the Air Ministry and the aircraft industry of the last two years in the military sphere have accentuated the neglect of civil attention, although it is now thought to be possible to give further assistance to civil aviation and to improve its organization.

The present report (Cmd. 5685. London : H.M. Stationery Office, 1938. 1s. 6d. net) is the outcome of a storm of Parliamentary criticism of British civil aviation in November last, which indeed led to the reconstruction of the membership of the original committee, and the contents of the report confirm the soundness and pertinence of much of that Parliamentary criticism. No one who reads the report or who followed the subsequent debate in the House of Commons can be in doubt as to the room or need for further and strenuous efforts in the field of civil aviation and world air transport, and the report should stimulate both interest and constructive criticism in this field. The need for the continuous pressure of informed opinion is sufficiently illustrated by the reference in the report to the failure to give full effect to the recommendations of the Maybury Committee on the development of civil aviation in the United Kingdom, although their acceptance by the Government was announced more than a year ago.

It should not, of course, be overlooked that the Government policy of concentrating on the development of Empire routes, which constitute 90 per cent of the total mileage operated by Imperial Airways Ltd., has to a large extent been fully justified, and that such services have advanced much further towards financial autonomy than the great majority of Continental routes, which, as was shown by M. Henri Bouché and is pointed out again in this report, are much more heavily subsidized. So, too, the report finds no evidence that Imperial Airways' services are less safe than those of any foreign company or that traffic considerations are allowed to outweigh prudence.

The report emphasizes the necessity of closely associating and co-ordinating four elements in civil air transport if successful development is to be assured. There is first the machinery of Government, covering such matters as the initiation of policy, consideration of the international implications of civil aviation, stimulating the development of aircraft, and controls required in the interests of safety. Then there is the aircraft operator, who will give practical effect to Government policy by developing air transport with energy and foresight. Thirdly, there is the aircraft constructor, and lastly the provision of essential ground organization.

The Committee recognizes that the military aspect of aviation cannot fundamentally be separated from the civil aspect, and emphasizes 
the necessity for much more virility in the initiation of policy and foresight in planning. The stimulation of research and design and the production of civil aircraft, as well as the encouragement of suitable organization of the aircraft industry, devolve upon the Secretary of State. Continuity in directing the policy of aircraft research, development and production is essential, and the Committee trenchantly criticizes the present system of expecting a military officer without previous knowledge and experience of such matters and holding office for a limited term to deal effectively with the situation.

The recommendation for the creation of a post of Permanent Under-Secretary of State for Air to assume control of this Department has already been accepted by the Government, as have further recommendations for the appointment of a Deputy Director of Civil Aviation and a Director of Civil Research and Production, and for strengthening the technical staff concerned with research and development. The Government, however, has not accepted the recommendation of the Committee that the functions of the Member for Research and Development on the Air Council, and also that part of the Department administered by the Air Member for Supply and Organization which deals with the production of aircraft, should be transferred to the Permanent Under-Secretary of State, as it is considered that such changes would seriously interrupt the work of the Service side of the Air Ministry.

In its observations on this question, the Government points out that the Department of Research and Development is already an extensive organization, largely civilian and permanent, the Director of Scientific Research being a permanent officer and a scientific worker of high repute. The Department is in close touch with other Government research establishments, with universities and with private firms, and its research and experimental establishments provide testing stations and a central laboratory for theoretical research. The Government contention that research and development on the Service side are in fact continuous and progressive, and that much of this work is of immediate value and available to makers of civil aircraft, is, however, not disputed by the Committee. Its contention is that, in the past, most of the research undertaken by the Air Ministry has had a military bias, and the reorganization recommended is intended to ensure that civil research work is given due prominence in future.
The tenor of the Government observations on the subject of research is accordingly less reassuring than might be desired, and the Prime Minister's silence on the subject in the debate is in itself disturbing. It is suggested, in fact, that instead of defence requirements drawing on the general body of scientific knowledge and applying it to the particular problems of defence, supplementing it by further investigation as required, in the field of aviation this policy is to be reversed and the trend of development dictated by Service requirements. This very policy has restricted and warped the whole development of civil aviation since the War, and it is optimistic to expect much improvement until the resources available for research and development in aviation are administered by those possessing not only the essential technical and administrative qualities, but are also trained to view the subject as a whole and not primarily in respect of Service requirements.

This is indeed the main point in the Committee's contention that the direction of aircraft research, development and production should be transferred from a military to a civil officer, not necessarily a technician, but possessing high ability, energy and proved capacity for organization. It is further supported by the reference to specific problems of research, such as the icing problem, with which two appendixes to the report deal in some detail. The prevention of ice formation is indeed a com. posite problem affecting the engines, airscrews, instruments, wireless equipment and the air frame itself, and the report insists that research into this problem should be prosecuted with the utmost vigour.

Other research problems to which the report directs special attention include such matters as pressure cabins, automatic blind landing equipment, anti-static electricity devices and the application of wireless to aviation purposes, in all of which evidence was submitted that Great Britain is not keeping pace with the United States of America, while special attention to lines of research which would make flying safer is also urged. It is indeed pointed out that unless a limit is soon put to the size of aerodromes, considerations of cost may prove a serious handicap to further progress, and on this ground alone a reduction in the landing speed of air liners without impairing performance in other respects is desirable.

Scientific workers can scarcely fail to be keenly interested in these technical problems as well as in the recommendations relating to policy and 
reorganization intended to give civil aviation some of the freedom of development of which it has been deprived largely by defence considerations. They will, however, be equally interested in the comments of the report on staff questions. Here the report is perhaps unduly reticent, and its criticism is implied rather than openly expressed. That it should be necessary for a report of this type to make the recommendation that personal contact between employer and employee in air transport should be supplemented by collective representation is a serious reflection on the management concerned, and its significance cannot be appreciated without regard to the great advance in dealing with staff matters characterizing largescale progressive industry in recent years. The fact that the Committee should find it necessary to recommend that dividends should be restricted to the limits usually associated with public utility companies-a principle with which the Prime Minister announced his sympathy-further indicates how far the managements of Imperial Airways or British Airways Ltd. has lagged behind the best practice and principles of modern management.
There can be no two opinions that the inquiry instituted has been thoroughly justified, and if the recommendations of the report are implemented there is reason to believe that civil aviation in Great Britain may be liberated from some of its shackles. None the less, it is clear from the Government observations that defence considerations remain the dominant factor, and it should not be forgotten that civil aviation can only gain its true freedom in the international sphere. Fundamentally, moreover, the report is a telling indictment of the management of the industry, and adds yet one more warning to others in the past of the dangers to the community of allowing control to remain in the hands of those who are incompetent to take long-range and progressive views, or to assess accurately and sympathetically the technical and human as well as the financial issues involved. In these days, when the resources at the disposal of scientific management are so vast and accessible, there is less excuse than ever for maladministration, and failure to ensure that those in control possess the administrative capacity for their task is more likely than any other factor to involve the downfall of social or industrial institutions to-day.

\section{Petroleum Technology}

The Science of Petroleum:

a Comprehensive Treatise of the Principles and Practice of the Production, Refining, Transport and Distribution of Mineral Oil. Editors: Dr. A. E. Dunstan, Prof. A. W. Nash, Dr. Benjamin T. Brooks, Sir Henry Tizard. Vol. 1. Pp. xxvi +836 . Vol. 2. Pp. xvi $+837-1670$. Vol. 3. Pp. xvi + 1671-2386. Vol.4. Pp. xvi + 2387-3192. (London: New York and Toronto : Oxford University Press, 1938.) 4 vols., £15 15s. 0d. net.

GVEN in an age of industrial achievement the L economic efficiency of the petroleum industry is outstanding. In particular, its products have been progressively and rapidly adjusted to the ever-changing requirements of a world largely based for its mechanized civilization upon the internal combustion engine. What is still more striking is that many of these adjustments have been made in advance of the engine-builder's demand for them. The designer has been encouraged in effect to produce more and more efficient units because of the special fuels and lubricants waiting to his hand. He now sets no limits to his requirements in this direction, for he knows from experience that the oil industry will serve him to the fullest extent of its resources even if it means scrapping (as often happens) the highly successful plant and process of the previous day.

This spirit of deliberate self-modernization is evident throughout the oil world. It is significant that the biggest technical advances and productive successes in the search for petroleum by geophysical means have been made at a time when visible reserves of oil are greater than ever in the past and when production in many quarters has had to be artificially restrained. It is equally worthy of mark at the other end of the scale that chief encouragement of the synthetic production of oil has come from the large petroleum undertakings, and not from the coal or similar interests, which might be expected most directly to benefit.

The great research stations of the petroleum industry and its modern refineries ; its geophysical surveying, high-pressure drilling and thousandmile pipe lines; its tanker fleets, its distribution organization and its resolute development of a new synthetic chemistry, all reflect a standard of technical and administrative attainment which it 